\title{
Tekanan Anggaran Waktu Memoderasi Pengaruh Role Stres Terhadap Perilaku Disfungsional Auditor
}

\author{
Christine Octo Debora Limbong1 \\ Fakultas Ekonomi dan Bisnis \\ Universitas Udayana, Indonesia \\ Email: christine.limbong@gmail.com
}

\author{
I Dewa Nyoman Badera ${ }^{2}$ \\ Fakultas Ekonomi dan Bisnis \\ Universitas Udayana, Indonesia
}

\begin{abstract}
ABSTRAK
Tujuan dari penelitian ini adalah menganalisis tekanan anggaran waktu memoderasi pengaruh role stres terhadap perilaku disfungsional auditor (Studi Pada PT Bank BNI Kanwil Denpasar). Penelitian ini dilakukan di seluruh kantor PT Bank BNI Kanwil Denpasar sebanyak tiga puluh dua kantor yang terdapat pada Wilayah Bali tahun 2019 dengan menjadikan auditor sebanyak 68 orang sebagai sampel dengan metode sample jenuh. Pengumpulan data dilakukan dengan menyebarkan kuesioner, di uji melalui teknik moderasi regresi analisis (MRA). Berdasarkan hasil analisis, variabel role stres berpengaruh positif signifikan terhadap perilaku disfungsional auditor pada PT Bank BNI Kanwil Denpasar. Tekanan anggaran waktu berpengaruh positif signifikan terhadap perilaku disfungsional auditor pada PT Bank BNI Kanwil Denpasar. Tekanan anggaran waktu memoderasi pengaruh role stres terhadap perilaku disfungsional auditor pada PT Bank BNI Kanwil Denpasar.
\end{abstract}

Kata Kunci: Role Stress; Tekanan Anggaran Waktu; Perilaku Disfungsional Auditor.

\section{Time Budget Pressure Moderates The Influence Of Role Stress On Auditor's Disfunctional Behavior}

\section{ABSTRACT}

The purpose of this study is to analyze the time budget pressure moderate the influence of the role of stress on the auditor's dysfunctional behavior (Study at PT Bank BNI Denpasar Regional Office). This research was conducted in all thirty-two offices of PT Bank BNI Denpasar Regional Officein the Bali Region in 2019 by making 68 auditors as samples using the saturated sample method. Data collection is done by distributing questionnaires, tested through regression analysis moderation (MRA) techniques. Based on the analysis, the role stress variable has a significant positive effect on the dysfunctional behavior of auditors at PT Bank BNI Denpasar Regional Office. Time budget pressure has a significant positive effect on the auditor's dysfunctional behavior at PT Bank BNI Denpasar Regional Office. Time budget pressure moderates the influence of role stress on the auditor's dysfunctional behavior at PT Bank BNI Denpasar Regional Office.

Keywords: Role Stress; Time Budget Pressure; Auditor's Dysfunctional Behavior.

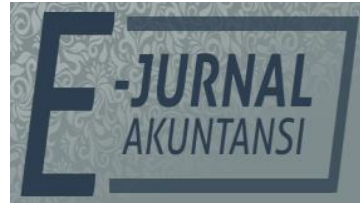

E-JA

e-Jurnal Akuntansi e-ISSN 2302-8556

Vol. 30 No. 3

Denpasar, Maret 2020

Hal. 733-745

Artikel Masuk: 17 November 2019

Tanggal Diterima: 4 Maret 2020 


\section{PENDAHULUAN}

Pada bank dengan skala besar seperti PT Bank Negara Indonesia (BNI), pengawasan akan lebih sulit dilakukan karena luasnya lingkup pengawasan, makan dari itu bank membutuhkan suatu lembaga untuk mengawasi dan mengevaluasi kinerja agar dapat dicapai hasil yang maksimal sesuai dengan tujuan umum bank (Kasmir, 2014). Hal ini dilakukan agar pengawasan dapat dilakukan secara menyeluruh dan secara teliti sehingga permasalahanpermasalahan yang muncul serta hal- hal yang tidak sesuai dengan perencanaan dapat diungkapkan secara tepat (Sari \& Suryanawa, 2016). Oleh karena itu, dibutuhkan suatu lembaga yang independen, obyektif, serta tidak berada di bawah pengaruh dan tekanan pihak lain untuk melakukan pengawasan dalam suatu bank. Kasmir (2014) menyatakan bahwa dengan adanya pihak yang independen diharapkan dapat memberikan bantuan kepada manajemen dalam menganalisis kebijakan maupun sistem pengendalian yang telah dibuat bank dalam mewujudkan tujuan yang telah direncanakan, sehingga kesalahan yang sama tidak akan terulang lagi di masa yang akan datang. Lembaga ini dikenal sebagai departemen internal audit (Harijanto, 2013).

Internal auditor merupakan bagian yang tak terpisahkan dari departemen internal audit. Internal audit merupakan pihak yang dianggap memiliki independensi dan obyektivitas tinggi sehingga diharapkan dapat melaksanakan tugasnya tanpa adanya tekanan dari pihak manapun. Dikdik (2008), menegaskan bahwa sebagai pihak yang independen, internal auditor lebih mudah untuk melihat adanya penyelewengan-penyelewengan yang dilakukan oleh pihak manajemen berkaitan dengan hasil kerja mereka dan hal-hal yang berkaitan dengan fungsi pengendalian intern. Internal auditor harus dapat secara maksimal memberikan kontribusinya demi peningkatan dan perkembangan bank.

PT Bank BNI Kanwil Denpasar untuk mengatasi terjadinya kecurangan (fraud) dibentuk audit internal sebagai biro pengawasan untuk mencegah kecurangan dalam suatu perusahaan yang kegiatannya meliputi menguji dan menilai efektivitas serta kecukupan sistem pengendalian internal yang ada dalam perusahaan. Peraturan Menteri Pendayagunaan Aparatur Negara Nomor 5 tahun 2008 tentang Standar Audit Aparat Pengawasan Intern, pada bagian pendahuluan secara eksplisit dan tegas dinyatakan bahwa "Pengawasan intern perusahaan merupakan fungsi manajemen yang penting dalam penyelenggaraannya (Surtikanti, 2016).

Kasus skandal keuangan yang sering dijumpai di Perbankan khususnya PT Bank BNI terjadinya masalah dalam penyaluran kredit seperti kredit fiktif yang akan menyebabkan kredit macet atau kredit bermasalah. Kredit macet atau kredit bermasalah merupakan suatu penyakit yang dapat menganggu dan mengancam sistem kegiatan bank, sehingga bank menjadi tidak sehat. Namun diakui bahwa sektor perkreditan tetap merupakan kegiatan yang penting dari suatu industri perbankan, karena "kredit" sebagai salah satu sumber dana yang penting untuk usaha perbankan. Masalah lainnya seperti kecurangan (fraud) sering diartikan sebagai perbuatan curang yang dilakukan dengan berbagai cara licik dan bersifat menipu serta sering tidak disadari oleh korban yang dirugikan. Di bidang perbankan, dapat diartikan sebagai tindakan sengaja melanggar 
ketentuan internal (kebijakan, sistem dan prosedur) dan peraturan perundangundangan yang berlaku demi kepentingan pribadi atau pihak lain yang berpotensi merugikan bank, baik material maupun moril. Dari kasus- kasus yang pernah terjadi di PT Bank BNI Kanwil Denpasar tidak sedikit pekerja yang diberhentikan secara tidak hormat dikarenakan terlibat dalam kasus kecurangan ini seperti kredit fiktif, penggunaan uang, penyalahgunaan wewenang dll.

Perilaku professional internal auditor salah satunya diwujudkan dalam bentuk menghindari perilaku menyimpang dalam audit atau biasa disebut perilaku disfungsional auditor (Andreas, 2016). Perilaku menyimpang dalam audit atau yang biasa disebut dengan disfungsional auditor behavior merupakan tindakan menyimpang yang dilakukan oleh auditor dalam melaksanakan tugasnya, sehingga tindakannya tersebut mencerminkan sikap ketidakjujuran dan tidak objektif dalam melaksanakan tugasnya (Pribadi, 2015). Perilaku disfungsional auditor antara lain adalah penghentian prosedur audit secara dini (premature sign-off), mengubah atau mengganti tahapan audit (replacing or altering of audit procedures) serta pelaporan waktu audit yang lebih pendek dari waktu yang sebenarnya (underreporting of time).

Timbulnya perilaku disfungsional audit yang dilakukan dalam menjalankan tugas dikarenakan seorang auditor rentan mengalami stress kerja akibat tekanan peran (role stress) (Harijanto, 2013). Stress karena peran atau tugas (role stress) yaitu kondisi dimana seseorang mengalami kesulitan dalam memahami apa yang menjadi tugasnya, peran yang dia mainkan dirasakan terlalu berat atau memainkan berbagai peran pada tempat mereka bekerja (Sari \& Suryanawa, 2016). Namun stres yang ditimbulkan sering berkaitan dengan adanya sebuah conflict peran dan ketidakjelasan peran di dalamnya. Penelitian (Dikdik, 2008) tentang tekanan peran (role stress) dalam profesi auditor independen memakai dua unsur pada tekanan peran, yaitu unsur yang berdasarkan pengalaman dan pandangan sesuai dengan sifat organisasi auditor independen.

Beberapa penelitian seperti Ermawati et al. (2014) menyatakan bahwa role stress berpengaruh positif terhadap perilaku disfungsional auditor. Harijanto (2013) menyatakan hal yang sama dimana role stress secara positif berpengaruh pada perilaku disfungsional auditor. Dikdik (2008) dalam penelitiannya membuktikan role stress memiliki pengaruh positif terhadap perilaku disfungsional auditor dalam melaksanakan audit perusahaan. Sari \& Suryanawa (2016) menyatakan role stress berpengaruh positif terhadap perilaku disfungsional auditor.

Harijanto (2013) menyatakan adanya role stress merupakan suatu hal yang cukup berpengaruh dalam suatu pekerjaan yang dimana tidak hanya tekanan terhadap pekerjaan akan tetapi perilaku yang menyimpang akan dilakukan oleh seorang auditor, terlepas dari itu adanya tekanan anggaran waktu (time budget pressure) dan cenderung kaku akan memotivasi auditor untuk melewati atau mengabaikan beberapa prosedur audit sehingga penugasannya dapat selesai pada waktunya tanpa memperhatikan kualitas audit. Time budget pressure telah menjadi masalah yang serius bagi auditor berkaitan dengan penugasan audit. Bahkan, beberapa auditor mengalami tekanan yang cukup besar ketika dihadapkan pada suatu penugasan audit dengan time budget yang sangat singkat 
dan tidak terukur (Suprianto, 2014). Tingkat time budget pressure yang tinggi akan mendorong auditor untuk melakukan perilaku disfungsional. Perilaku disfungsional auditor tentu saja akan mempengaruhi kualitas audit.

Sukendra et al. (2015) menyatakan dalam penelitiannya time budget pressure memiliki pengaruh positif terhadap perilaku disfungsional auditor. Adnyani et al. (2014) menyatakan time budget pressure secara positif mempengaruhi perilaku disfungsional auditor. Septiani \& Sukartha (2017) menyatakan perilaku disfungsional auditor dipengaruhi oleh adanya time budget pressure. Suprianto (2014) menyatakan dalam penelitiannya time budget pressure memiliki pengaruh positif terhadap perilaku disfungsional auditor. Fitria (2016) menyatakan time budget pressure secara positif mempengaruhi perilaku disfungsional auditor.

Perilaku disfungsional auditor timbul karena adanya dilemma suatu tekanan terhadap anggaran waktu audit yang telah disusun dan tekanan pekerjaan yang mengakibatkan role stress bagi seorang auditor Nor et al. (2017). Time budget pressure (tekanan anggaran waktu) adalah faktor yang mempengaruhi kualitas audit. Time budget pressure (tekanan anggaran waktu) sebagai variabel moderasi membuat seorang auditor bekerja dalam kondisi yang tertekan (dalam waktu) membuat auditor cenderung stress dan berperilaku disfungsional. Time budget pressure (tekanan anggaran waktu) mengakibatkan perilaku menyimpang auditor yang dapat memberikan implikasi stress dan berperilaku disfungsional. Dilemma ini disebabkan karena ketidakseimbangan antara beban kerja yang diterima oleh auditor dengan kualitas audit yang diatur oleh standar profesional.

Beberapa penelitian seperti Septiani \& Sukartha (2017) menyatakan bahwa time budget pressure dapat memoderasi pengaruh role stress terhadap perilaku disfungsional auditor. Harijanto (2013) menyatakan hal yang sama dimana time budget pressure memoderasi pengaruh role stress secara positif pada perilaku disfungsional auditor. Ermawati et al. (2014) dalam penelitiannya membuktikan time budget pressure memoderasi pengaruh positif role stress terhadap perilaku disfungsional auditor dalam melaksanakan audit perusahaan. Devi \& Suaryana (2016) menyatakan time budget pressure memoderasi pengaruh role stress secara positif pada perilaku disfungsional auditor.

Penelitian ditujukan untuk membuktikan secara empiris pengaruh role stress terhadap perilaku disfungsional auditor di PT Bank BNI Kanwil Denpasar, pengaruh tekanan anggaran waktu pada perilaku disfungsional auditor di PT Bank BNI Kanwil Denpasar, tekanan anggaran waktu memoderasi pengaruh role stress pada perilaku disfungsional auditor di PT Bank BNI Kanwil Denpasar.

Nor et al. (2017) mengatakan bahwa sikap (attitudes) merupakan suatu penilaian yang melibatkan penalaran logis sadar atas gambaran suatu keyakinan, penilaian atas perasaan, dan suatu intensi (niatan) perilaku terhadap seseorang, obyek, atau peristiwa yang disebut dengan attitude object. Theory of attitude change terdiri atas berbagai macam teori yang dinaunginya, contohnya Dissonance Theory dan Functional Theory. Dissonance theory menjelaskan bahwa ketidaksesuaian memotivasi seseorang untuk mengurangi atau mengeliminasi ketidaksesuaian tersebut. Sedangkan Functional Theory dari perubahan sikap menyatakan bahwa sikap berlaku untuk memenuhi kebutuhan seseorang (Yuen et al., 2012). 
Menurut (Arens et al., 2012) auditor dapat dibedakan menjadi tiga jenis. Pertama, auditor pemerintah adalah auditor yang bertugas melakukan audit atas keuangan Negara pada instansi-instansi pemerintah. Kedua, eksternal auditor atau akuntan publik adalah seorang praktisi dan gelar professional yang diberikan kepada akuntan di Indonesia yang telah mendapat izin untuk memberikan jasa audit umum dan review atas laporan keuangan. Terakhir, internal auditor merupakan auditor yang bekerja suatu perusahaan dan oleh karenanya berstatus sebagai pegawai pada perusahaan tersebut.

Perilaku disfungsional audit dapat memberikan pengaruh pada kualitas audit, baik secara langsung maupun tidak langsung. Perilaku yang dapat memengaruhi kualitas audit secara tidak langsung adalah underreporting of time (Ismail, 2016). Perilaku under reporting of time terjadi ketika auditor menyelesaikan pekerjaan yang dibebankan tetapi tidak melaporkan waktu yang sebenarnya untuk menyelesaikan pekerjaan tersebut. Perilaku underreporting of time oleh auditor bisa terjadi karena auditor memiliki kecenderungan untuk menyelesaikan tugas audit sesuai dengan batas waktu yang dianggarkan, dengan tujuan untuk memeroleh evaluasi kinerja personal yang lebih baik (Ismail, 2016).

Robbins \& Judge (2008) menyebutkan, ketika menghadapi tekanan anggaran waktu, auditor akan memberikan respon dengan dua cara, yaitu; fungsional dan disfungsional. Tipe fungsional adalah perilaku auditor untuk bekerja lebih baik dan menggunakan waktu sebaik-baiknya, hal ini sesuai juga dengan pendapat yang dikemukakan oleh (Harijanto, 2013), yang mengatakan bahwa anggaran waktu diidentifikasikan sebagai suatu potensi untuk meningkatkan penilaian audit (audit judgement) dengan mendorong auditor lebih memilih informasi yang relevan dan menghindari penilaian yang tidak relevan.

Penelitian Ermawati et al. (2014) menyatakan bahwa role stress berpengaruh positif terhadap perilaku disfungsional auditor. Harijanto (2013) menyatakan hal yang sama dimana role stress secara positif berpengaruh pada perilaku disfungsional auditor. Dikdik (2008) dalam penelitiannya membuktikan role stress memiliki pengaruh positif terhadap perilaku disfungsional auditor dalam melaksanakan audit perusahaan. Sari \& Suryanawa (2016) menyatakan role stress berpengaruh positif terhadap perilaku disfungsional auditor.

$\mathrm{H}_{1}$ : Role stress berpengaruh positif pada prilaku disfungsional auditor.

Beberapa penelitian seperti Sukendra et al. (2015) menyatakan dalam penelitiannya time budget pressure memiliki pengaruh positif terhadap perilaku disfungsional auditor. Adnyani et al. (2014) menyatakan time budget pressure secara positif mempengaruhi perilaku disfungsional auditor. Septiani \& Sukartha (2017) menyatakan perilaku disfungsional auditor dipengaruhi oleh adanya time budget pressure. Suprianto (2014) menyatakan dalam penelitiannya time budget pressure memiliki pengaruh positif terhadap perilaku disfungsional auditor. Fitria (2016) menyatakan time budget pressure secara positif mempengaruhi perilaku disfungsional auditor.

$\mathrm{H}_{2}$ : Tekanan anggaran waktu berpengaruh positif pada perilaku disfungsional auditor. 
Beberapa penelitian seperti Septiani \& Sukartha (2017) menyatakan bahwa time budget pressure dapat memoderasi pengaruh role stress terhadap perilaku disfungsional auditor. Harijanto (2013) menyatakan hal yang sama dimana time budget pressure memoderasi pengaruh role stress secara positif pada perilaku disfungsional auditor. Ermawati et al. (2014) dalam penelitiannya membuktikan time budget pressure memoderasi pengaruh positif role stress terhadap perilaku disfungsional auditor dalam melaksanakan audit perusahaan. (Devi \& Suaryana, 2016) menyatakan time budget pressure memoderasi pengaruh role stress secara positif pada perilaku disfungsional auditor. Berdasarkan uraian diatas, maka hipotesis yang dapat dirumuskan hasil penelitian sebagai berikut:

$\mathrm{H}_{3}$ : Tekanan anggaran waktu memperkuat pengaruh role stress terhadap perilaku disfungsional auditor.

Kerangka konseptual merupakan hubungan logis dari landasan teori dan kajian empiris. Kerangka konseptual menunjukkan pengaruh antar variabel dalam penelitian. Kerangka konseptual dalam penelitian ini disajikan pada Gambar 1. berikut ini.

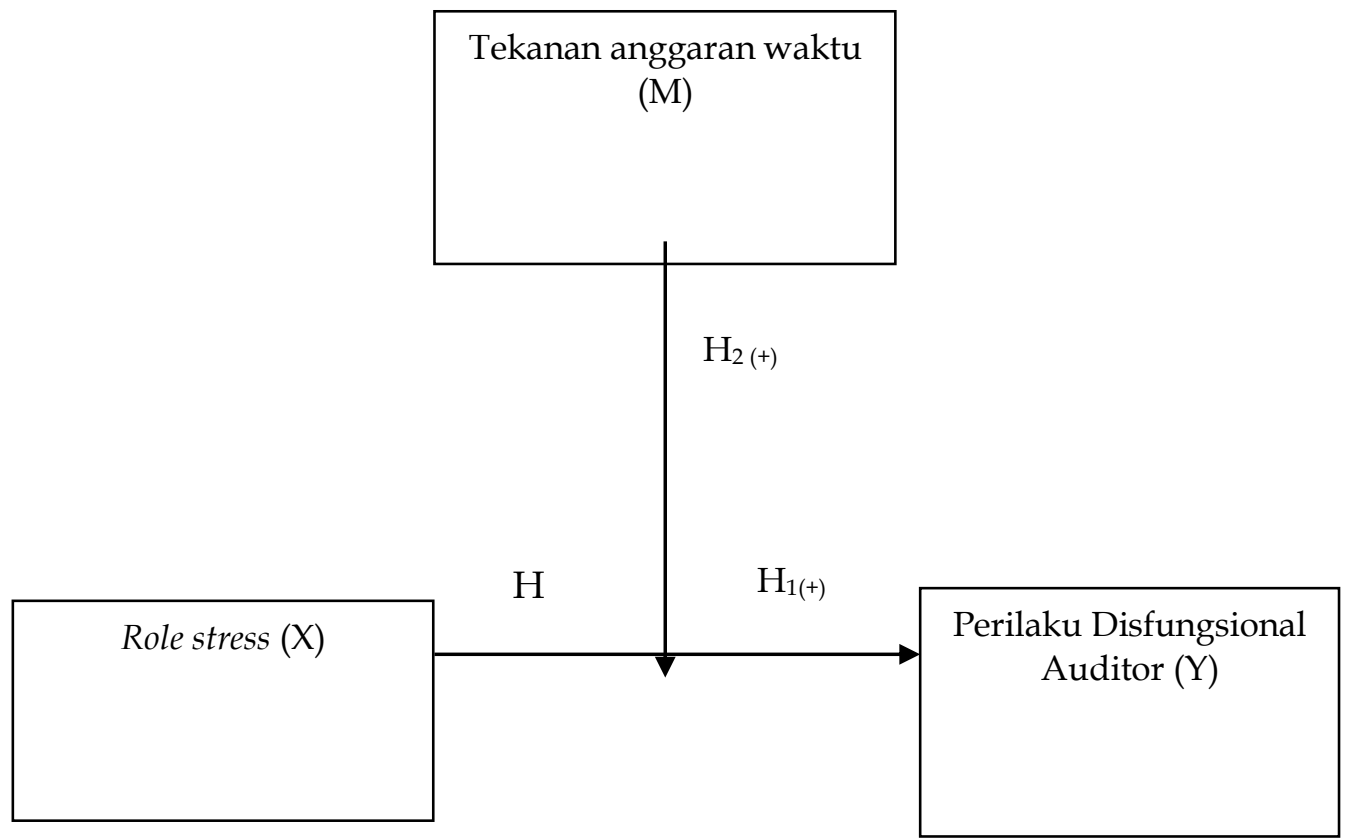

Sumber: Data Penelitian, 2019

Gambar 1. Model Kerangka Konseptual

\section{METODE PENELITIAN}

Berdasarkan permasalahan yang diteliti, penelitian ini digolongkan pada penelitian asosiatif (hubungan), yaitu penelitian yang bertujuan untuk mengetahui hubungan dari variabel atau lebih (Sugiyono, 2010). Objek penelitian dalam penelitian ini adalah tekanan anggaran waktu memoderasi pengaruh role stress terhadap perilaku disfungsional auditor. Jenis data kuantitatif dan kualitatif yang dipergunakan seperti berupa angka-angka atau data yang dapat dihitung seperti data tanggapan responden terhadap kuesioner yang diberikan, jumlah sampel responden. Data kualitatif adalah data yang bukan merupakan angka dan tidak dapat dihitung yang mempunyai kaitan dengan permasalahan 
yang dibahas seperti sejarah singkat perusahaan, dan struktur organisasi perusahaan. Sumber data primer dan sekunder yang dipergunakan seperti observasi dan pemberian kuesioner kepada responden, sejarah berdirinya perusahaan, dan jumlah pelanggan. Secara sistematis desain penelitian yang digunakan pada penelitian ini dapat digambarkan sebagai berikut.

Jumlah sampel adalah 68 orang internal auditor dengan menggunakan pengambilan sampel dengan metode sensus (Sugiyono, 2017). Data yang dikumpulkan dalam penelitian ini menggunakan metode wawancara, pustaka dan kuesioner yang diberikan kepada responden yang telah dipilih.

Uji validitas menyatakan sebuah instrumen dikatakan valid jika item yang mempunyai korelasi positif dengan kriterum (skor total) serta korelasi tinggi menunjukkan bahwa item tersebut mempunyai validitas yang tinggi pula. Syarat minimum untuk dianggap memenuhi syarat adalah kalau $r=0,3^{\prime \prime}$. Uji reabilitas ditunjukkan dengan angka indeks yang konsistensi suatu alat ukur dalam mengukur gejala yang sama. Uji reabilitas mampu menunjukan sejauh mana instrument dapat dipercaya dan diharapkan. Nilai suatu instrumen dikatakan reliabel bila nilai Alpha Cronbach $\geq 0,6$.

Uji asumsi klasik digunakan untuk memperoleh model analisis yang tepat, dimana model regresi yang tepat harus menghindari kemungkinan terjadinya penyimpangan asumsi klasik. Uji asumsi klasik yang harus dilakukan terhadap data pada penelitian ini adalah 1) uji normalitas, untuk mengetahui apakah nilai residual yang telah distandarisasi pada model regresi berdistribusi secara normal atau tidak. Dikatakan berdistribusi normal jika nilai residual mendekati nilai rata-ratannya (Ghozali, 2009). 2) uji heteroskedastisitas, digunakan untuk mengetahui apakah model regresi yang berbentuk sudah bersifat homoskedastisitas (Ghozali, 2009). 3) uji multikolinearitas, digunakan untuk melihat pembentukan korelasi yang tinggi atau sempurna diantara variabel bebas atau tidak. Jika terjadi korelasi yang tinggi dapat dikatakan terjadi murtikolinearritas.

Setelah data-data yang dibutuhkan diperoleh, selanjutnya dilakukan analisis sehingga data tersebut lebih berarti. Teknik perhitungan dan analisis data menggunakan Moderating Regression Analysis. Moderating Regression Analysis dinyatakan dalam bentuk regresi berganda dengan persamaan mirip regressi polynomial yang menggambarkan pengaruh nonlinier (Ghozali, 2009; 47) yang dinyatakan dalam bentuk model persamaan sebagai berikut.

$Y=\alpha+\beta_{1} X+\beta_{2} M_{1}+\beta_{3}(X M)+\varepsilon$

Uji signifikansi parameter individual digunakan untuk menguji signifikansi koefisien regresi atau pengaruh secara parsial dari variabel bebas terhadap variabel terikat yaitu dengan membandingkan $t_{\text {tabel }}$ dan $t_{\text {hitung. }}$. Masingmasing $t$ hasil perhitungan ini kemudian dibandingkan dengan $t_{\text {tabel }}$ yang diperoleh dengan menggunakan taraf nyata 0,05 .

\section{HASIL DAN PEMBAHASAN}

Tabel 1. menunjukkan bahwa masih-masing indikator variabel memiliki nilai person correlation lebih besar dari 0,30, maka ini berarti indikator/pertanyaan 
yang digunakan layak digunakan untuk mengukur apa yang seharusnya diukur, dan dapat mengungkap data dari variabel yang diteliti secara tepat.

Tabel 1. Rangkuman Hasil Uji Validitas

\begin{tabular}{lll}
\hline Variabel & Instrumen & Pearson Correlation \\
\hline \multirow{3}{*}{ Role stress $(\mathrm{X})$} & $\mathrm{X}_{1.1}$ & 0,849 \\
& $\mathrm{X}_{1.2}$ & 0,768 \\
& $\mathrm{X}_{1.3}$ & 0,744 \\
& $\mathrm{X}_{1.4}$ & 0,802 \\
& $\mathrm{M}_{1.1}$ & 0,657 \\
Tekanan anggaran waktu $(\mathrm{M})$ & $\mathrm{M}_{1.2}$ & 0,848 \\
& $\mathrm{M}_{1.3}$ & 0,873 \\
& $\mathrm{M}_{1.4}$ & 0,690 \\
& $\mathrm{M}_{1.5}$ & 0,729 \\
Perilaku disfungsional audit $(\mathrm{Y})$ & $\mathrm{Y}_{1}$ & 0,860 \\
& $\mathrm{Y}_{2}$ & 0,821 \\
& $\mathrm{Y}_{3}$ & 0,877 \\
\hline
\end{tabular}

Sumber: Data Penelitian, 2019

Tabel 2. menggambarkan nilai Cronbach's Alpha untuk masing-masing variabel $>0,6$, ini berarti alat ukur tersebut akan memberikan hasil yang konsisten apabila alat ukur tesebut digunakan kembali untuk meneliti obyek yang sama.

Tabel 2. Hasil Uji Reliabilitas

\begin{tabular}{|c|c|}
\hline Variabel & Cronbach's Alpha \\
\hline Role stress $(\mathrm{X})$ & 0,798 \\
\hline Tekanan anggaran waktu (M) & 0,817 \\
\hline Perilaku disfungsional audit $(\mathrm{Y})$ & 0,806 \\
\hline
\end{tabular}

Sumber: Data Penelitian, 2019

Berdasarkan Tabel 3. data dikatakan berdistribusi normal jika taraf signifikansi lebih besar dari 0,05. Diketahui nilai signifikansi sebesar 0,370 (0,370 $>0,05)$. Hal ini berarti model regresi berdistribusi normal.

Tabel 3. Hasil Uji Kolmogorov-Smirnov

\begin{tabular}{lll}
\hline & & $\begin{array}{l}\text { Unstandardized } \\
\text { Residual }\end{array}$ \\
\hline $\mathrm{N}$ & & 68 \\
Normal Parameters $(\mathrm{a}, \mathrm{b})$ & Mean & 0,0000000 \\
& Std, Deviation & 2,00473189 \\
Most Extreme Differences & Absolute & 0,111 \\
& Positive & 0,072 \\
& Negative & $-0,111$ \\
Kolmogorov-Smirnov Z & & 0,917 \\
Asymp. Sig. (2-tailed) & & 0,370 \\
\hline
\end{tabular}

Sumber: Data Penelitian, 2019

Berdasarkan Tabel 4. dapat dilihat bahwa nilai tolerence masing-masing variabel lebih kecil dari 0,1 dan nilai VIF lebih besar dari 10, sehingga dapat disimpulkan bahwa dalam model regresi tidak terjadi multikolinearitas dan dapat digunakan dalam penelitian. 
Tabel 4. Hasil Uji Multikolinearitas

\begin{tabular}{lll}
\hline Variabel & Tolerance & VIF \\
\hline Role stress $(\mathrm{X})$ & 0,032 & 11,445 \\
Tekanan anggaran waktu $(\mathrm{M})$ & 0,049 & 11,517 \\
\hline
\end{tabular}

Sumber: Data Penelitian, 2019

Uji heteroskedastisitas bertujuan untuk menguji apakah model regresi terjadi ketidaksamaan varians dari residual pengamatan ke pengamatan yang lain. Jika tingkat signifikansi berada di atas 0,05 maka model regresi ini bebas dari masalah heteroskedastisitas.

Tabel 5. Hasil Uji Heteroskedastisitas

\begin{tabular}{lll}
\hline Variabel & Sig. & Keterangan \\
\hline Role stress $(\mathrm{X})$ & 0,944 & Bebas heteroskedastisitas. \\
Tekanan anggaran waktu $(\mathrm{M})$ & 0,880 & Bebas heteroskedastisitas \\
\hline
\end{tabular}

Sumber: Data Penelitian, 2019

Berdasarkan Tabel 5. dapat dilihat bahwa nilai sig masing-masing variabel lebih besar dari 0,05 yang berarti variabel tersebut bebas heteroskedastisitas.

Tabel 6. Hasil Statistik Deskriptif

\begin{tabular}{|c|c|c|c|c|c|}
\hline Variabel & $\mathrm{N}$ & Min. & Max. & Mean & Std. Deviasi \\
\hline Role stress & 68 & 8 & 19 & 15,01 & 2,924 \\
\hline Tekanan anggaran waktu & 68 & 12 & 25 & 18,84 & 3,651 \\
\hline $\begin{array}{l}\text { Role stress-Tekanan } \\
\text { anggaran waktu }\end{array}$ & 68 & 96 & 456 & 288,57 & 94,945 \\
\hline $\begin{array}{l}\text { Perilaku disfungsional } \\
\text { audit }\end{array}$ & 68 & 6 & 15 & 11,12 & 2,501 \\
\hline
\end{tabular}

Sumber: Data Penelitian, 2019

Tabel 6 dapat dilihat bahwa variabel role stress $(X)$ memiliki nilai minimum sebesar 8 , nilai maksimum sebesar 19 , mean sebesar 15,01, dan standar deviasi sebesar 2,924. Ini berarti bahwa terjadi perbedaan role stress yang diteliti terhadap nilai rata-ratanya sebesar 2,924 .

Variabel tekanan anggaran waktu (M) memiliki nilai minimum sebesar 12, nilai maksimum sebesar 25, mean sebesar 18,84, dan standar deviasi sebesar 3,651 . Ini berarti bahwa terjadi perbedaan nilai tekanan anggaran waktu yang diteliti terhadap nilai rata-ratanya sebesar 3,651.

Variabel role stress $(\mathrm{X})$ - tekanan anggaran waktu $(\mathrm{M})$ memiliki nilai minimum sebesar 96, nilai maksimum sebesar 456, mean sebesar 288,57, dan standar deviasi sebesar 94,945. Ini berarti bahwa terjadi perbedaan nilai role stress $(\mathrm{X})$ - tekanan anggaran waktu $(\mathrm{M})$ yang diteliti terhadap nilai rata-ratanya sebesar 26,610.

Variabel perilaku disfungsional audit $(\mathrm{Y})$ memiliki nilai minimum sebesar 6 , nilai maksimum sebesar 15 , mean sebesar 11,12, dan standar deviasi sebesar 2,501. Ini berarti bahwa terjadi perbedaan nilai perilaku disfungsional audit yang diteliti terhadap nilai rata-ratanya sebesar 2,501.

Nilai Koefisien $\beta_{1}$ yang diperoleh sebesar 0,988 menunjukan bahwa interaksi antara variabel role stress dan perilaku disfungsional audit bersifat 
positif. Artinya interaksi role stress berpengaruh terhadap perilaku disfungsional audit di PT. Bank BNI Kanwil Denpasar.

Tabel 7. Hasil Pelaporan Analisis MRA

\begin{tabular}{|c|c|c|c|c|c|}
\hline \multirow[b]{2}{*}{ Variabel } & & \multicolumn{3}{|c|}{ Koefisien Regresi } & \multirow[b]{2}{*}{ Sig } \\
\hline & & B & $\begin{array}{l}\text { Std. } \\
\text { error }\end{array}$ & $\mathrm{t}$ & \\
\hline \multicolumn{2}{|l|}{ (constant) } & 10.517 & 0.368 & & \\
\hline \multicolumn{2}{|l|}{ Role stress } & 0.988 & 0.301 & 3.280 & .002 \\
\hline \multicolumn{2}{|c|}{ Tekanan anggaran waktu } & 0.643 & 0.309 & 2.083 & 041 \\
\hline \multicolumn{2}{|c|}{ Role stress- Tekanan anggaran waktu $|\mathrm{ZXM}|$} & 0,872 & 0.395 & 2.210 & .031 \\
\hline Dependen variabel & : $\quad$ perilaku dis & hal audit & & & \\
\hline F Statistik & 11.867 & & & & \\
\hline Sig F & 0.000 & & & & \\
\hline $\mathrm{R}^{2}$ & 0.957 & & & & \\
\hline
\end{tabular}

Sumber: Data Penelitian, 2019

Persamaan regresi pada Tabel 7. dapat dijelaskan untuk setiap variabel halhal sebagai berikut:

$$
\mathrm{Y}=0,988 \mathrm{X}+0,643 \mathrm{M}+0,872|\mathrm{ZXM1}|
$$

Nilai Koefisien $\beta_{2}$ yang diperoleh sebesar 0,643 menunjukan bahwa interaksi antara variabel tekanan anggaran waktu dan perilaku disfungsional audit bersifat positif. Artinya interaksi tekanan anggaran waktu berpengaruh terhadap perilaku disfungsional audit di PT. Bank BNI Kanwil Denpasar.

Nilai Koefisien $\beta_{3}$ yang diperoleh sebesar 0,872 menunjukan bahwa interaksi antara variabel tekanan anggaran waktu dan role stress bersifat positif. Artinya interaksi tekanan anggaran waktu memperkuat pengaruh role stress terhadap perilaku disfungsional audit di PT. Bank BNI Kanwil Denpasar.

Hasil uji statistik $F$, menunjukan hasil nilai siginifikansi sebesar 0,000 yang lebih kecil dari tingkat $a=0,05$. Hal ini berarti role stress dan tekanan anggaran waktu secara bersama berpengaruh signifikan terhadap perilaku disfungsional audit di PT. Bank BNI Kanwil Denpasar.

Hasil perhitungan uji $t$ dapat diketahui bahwa nilai koefisien regresi $X$ adalah sebesar 3,280 dengan tingkat signifikansi sebesar 0,002 lebih kecil dibandingkan dengan taraf nyata $a=0,05$. Hal ini menunjukan bahwa role stress berpengaruh positif dan signifikan terhadap perilaku disfungsional audit di PT. Bank BNI Kanwil Denpasar.

Hasil perhitungan uji $\mathrm{t}$ dapat diketahui bahwa nilai koefisien regresi $\mathrm{M}$ adalah sebesar 2,083 dengan tingkat signifikansi sebesar 0,041 lebih kecil dibandingkan dengan taraf nyata $\alpha=0,05$. Hal ini menunjukan bahwa tekanan anggaran waktu berpengaruh positif dan signifikan terhadap perilaku disfungsional audit di PT. Bank BNI Kanwil Denpasar.

Hasil perhitungan uji $\mathrm{t}$ dapat diketahui bahwa nilai koefisien regresi |ZXM | adalah sebesar 2,083 dengan tingkat signifikansi sebesar 0,031 lebih kecil dibandingkan dengan taraf nyata $a=0,05$. Hal ini menunjukan bahwa tekanan anggaran waktu yang dirasakan oleh seorang auditor mampu memoderasi pengaruh positif role stress yang dirasakannya terhadap perilaku disfungsional audit.

Berdasarkan Tabel 8. menunjukan bahwa nilai adjusted $\mathrm{R}$ square model 0,957 atau sebesar $95,7 \%$ artinya sebesar $95,7 \%$ variasi perilaku disfungsional 
audit dapat dijelaskan oleh variasi variabel dalam model tersebut yaitu role stress dan tekanan anggaran waktu.

Hasil uji parsial menunjukan bahwa role stress berpengaruh positif dan signifikan terhadap perilaku disfungsional auditor pada PT Bank BNI Kanwil Denpasar. Attitude change theory menjelaskan perilaku stress yang berlebihan akan menempatkan tuntutan yang tidak dapat dicapai, yang mengakibatkan hasil pekerjaan menurun. Hal ini relevan dengan tingkat stres yang tinggi yang berpengaruh terhadap karakteristik personal auditor sehingga melakukan perilaku disfungsional audit (Nor et al., 2017). Hasil penelitian ini sesuai dengan beberapa penelitian yang dilakukan oleh Dikdik (2008); Ermawati et al. (2014); Harijanto (2013); Sari \& Suryanawa (2016).

Hasil uji parsial menunjukan bahwa tekanan anggaran waktu berpengaruh positif dan signifikan terhadap perilaku disfungsional auditor pada PT Bank BNI Kanwil Denpasar. Theory of attitude change memprediksi sikap dan perilaku yang terdiri atas berbagai macam teori yang dinaunginya yang menyatakan time budget presure berperan dalam menciptakan perilaku disfungsional seorang auditor (Robbins \& Judge, 2008). Hasil penelitian ini sesuai dengan beberapa penelitian yang dilakukan oleh Fitria (2016); Septiani \& Sukartha (2017); Sukendra et al. (2015); Suprianto (2014).

Hasil uji parsial menunjukan bahwa tekanan anggaran waktu memperkuat pengaruh positif dan signifikan role stress terhadap perilaku disfungsional auditor pada PT Bank BNI Kanwil Denpasar. Theory of attitude change menyarankan auditor harus menggunakan keahlian profesionalnya untuk menghindari terjadinya tekanan anggaran waktu. Auditor harus menggunakan keahliannya dengan cermat untuk rencanakan prosedur audit dan mengevaluasi bukti yang diperoleh, dengan demikian auditor akan dapat menghindari terjadinya tekanan anggaran waktu yang mempengaruhi perilaku disfungsional auditor (Endrawes \& Monroe, 2012). Hasil penelitian ini sesuai dengan beberapa penelitian yang dilakukan oleh Devi \& Suaryana, (2016); Ermawati et al. (2014); Harijanto (2013); Septiani \& Sukartha (2017).

\section{SIMPULAN}

Berdasarkan pada pembahasan pada bab-bab sebelumnya, maka adapun hal-hal yang dapat disimpulkan yaitu role stress berpengaruh positif signifikan terhadap perilaku disfungsional auditor pada PT Bank BNI Kanwil Denpasar. Tekanan anggaran waktu berpengaruh positif signifikan terhadap perilaku disfungsional auditor pada PT Bank BNI Kanwil Denpasar. Tekanan anggaran waktu memoderasi pengaruh positif role stress berpengaruh positif signifikan terhadap perilaku disfungsional auditor pada PT Bank BNI Kanwil Denpasar.

Berdasarkan simpulan, saran-saran yang dapat diberikan seorang auditor yang mengalami tingkat role stress cenderung mempermasalahkan tuntutan pekerjaannya yang tidak sesuai dengan kemampuan yang dimilikinya, sebagai pihak yang bertanggung jawab kantor Inspeksi PT Bank BNI Kanwil Denpasar harus memperhatikan segala pekerjaan yang dibebankan kepada auditor seperti jumlah pemeriksaan, waktu pemeriksaan untuk pelaporan yang akan membantu pihak auditor untuk bekerja secara baik dan mengurangi perilaku disfungsional. Tekanan anggaran waktu yang menjadi perhatian bagi seorang auditor sampai 
saat ini mengenai pemahaman terhadap time budget, maka dari itu auditor harus mampu mengatur sebaik-baiknya pelaksanaan audit yang dilakukan dengan pemahaman job base dalam audit, pertimbangan waktu yang dibutuhkan sehingga mampu menyelesaikan tugas audit tanpa melakukan perilaku disfungsional. Perilaku disfungsional yang dilakukan auditor menjadi masalah yang mendapatkan perhatian khusus sampai saat ini.

\section{REFERENSI}

Arens, Randal, E., \& Beasley, M. S. (2012). Auditing and Assurance Services: An integrated Approach. Fourteenth Edition.

Adnyani, N., Atmadja, A. T., \& Herawati, N. T. (2014). Pengaruh Skeptisme Profesional Auditor, Independensi, dan Pengalaman Auditor Terhadap Tanggungjawab Auditor Dalam Mendeteksi Kecurangan dan Kekeliruan Laporan Keuangan (Studi Kasus pada Kantor Akuntan Publik (KAP) Wilayah Bali). E-Journal S1 AK Universitas Pendidikan Ganesha.

Andreas. (2016). Interaction between Time Budget Pressure and Professional Commitment towards Underreporting of Time Behavior. Procedia - Social and Behavioral Sciences. https://doi.org/10.1016/j.sbspro.2016.04.047

Devi, M. L. S., \& Suaryana, I. G. N. . (2016). Time Budget Pressure Memoderasi Pengaruh Karakteristik Personal Auditor terhadap Penerimaan Perilaku Disfungsional Audit. E-Jurnal Akuntansi, 15(3), 1994-2023.

Dikdik, A. (2008). Pengaruh Role tress Terhadap Perilaku Disfungsional Internal Auditor. Dimensia.

Endrawes, M., \& Monroe, G. S. (2012). Professional scepticism of auditors: a cross cultural experiment. Http:/Www.Unisa.Edu.Au/Global/Business/Centres/Cags/Docs/Seminars/Medh at\%20G\%20Mon Roe\%20paper\% 20June\%2027\%202012.Pdf.

Ermawati, M. D., Sinarwati, N. K., \& Sujana, E. (2014). Pengaruh Role Stress Terhadap Kinerja Auditor Dengan Emotional Quetiont Sebagai Variabel Moderating ( Studi Empiris pada Kantor Akuntan Publik Di Bali ). EJournal Akuntansi Universitas Pendidikan Ganesha.

Fitria, M. (2016). Pengaruh Time Budget Pressure, Due Profesional Care dan Eika Auditor Terhadap Kualitas Audit dengan Perilaku Disfungsional Auditor sebagai mediator (Study Empiris Pada Kantor Akuntan Publik Di Pekanbaru Dan Medan). Jurnal JOM F-KOM, 3(1), 119-132. https:/ / doi.org/10.7763/JOEBM.2015.V3.200

Ghozali, I. (2009). Aplikasi Analisis Multivariate dengan Program SPSS (2nd ed.). Semarang: Badan Penerbit Universitas Diponegoro.

Harijanto, D. (2013). The Influence of Role Conflict and Role Ambiguity on The Employee's Performance Through Commitment and SelfEfficacy (Study on the Nurses at Public Health Service Center of Kabupaten Kediri, East Java). IOSR Journal of Business and Management. https:// doi.org/10.9790/487x-08198105

Ismail, F. (2016). Pengaruh Tipe Kepribadian, Pengalaman Dan Penerimaan Perilaku Disfungsional Terhadap Audit Judgment. ESENSI. https:// doi.org/10.15408/ess.v5i2.2348 
Kasmir. (2014). Dasar-Dasar Perbankan. Edisi Revisi. Jakarta: PT Raja Grafindo Persada.

Nor, M. N. M., Smith, M., Ismail, Z., \& Taha, R. (2017). The Effect of Time Budget Pressure on Auditors' Behaviour. Journal of American Scientific Publishers, 23(1), 356-360.

Pribadi, K. (2015). Pengaruh Karakteristik Personal dan Faktor Lingkungan Terhadap Penerimaan Perilaku Disfungsional Auditor. Jurnal Ekonomi Informasi Akuntasi. Jurnal Ekonomi Informasi Akuntasi, 1(1), 1-25.

Robbins, S. P., \& Judge, T. A. (2008). Perilaku Organisasi Edisi ke-12. Jakarta: Salemba Empat. https:// doi.org/10.24843/jiab.2019.v14.i01.p11

Sari, N. E. R., \& Suryanawa, I. (2016). Konflik Peran, Ketidakjelasan Peran, Dan Kelebihan Peran Terhadap Kinerja Auditor Dengan Tekanan Waktu Sebagai Pemoderasi. E-Jurnal Akuntansi.

Septiani, I. N. M., \& Sukartha, I. M. (2017). Pengaruh Kompleksitas Audit dan Skeptisme Profesional Auditor pada Penerimaan Perilaku Disfungsional Audit. E-Jurnal Akuntansi, 18(1), 471-499.

Septiani, N. M. I., \& Sukartha, I. M. (2017). Pengaruh Kompleksitas Audit Dan Skeptisme Profesional Auditor Pada Penerimaan Perilaku Disfungsional Audit. E-Jurnal Akuntansi.

Sugiyono. (2010). Metode Penelitian Bisnis. Pendekatan Kuantitatif, kualitatif dan R \& D. Bandung: Alfabeta.

Sugiyono. (2017). Metode Penelitian Bisnis. Bandung: CV. Alfabeta.

Sukendra, P., Yuniarta, G. A., \& Atmadja, A. T. (2015). Pengaruh Skeptisme Profesional Auditor, Pengalaman Auditor Dan Keahlian Audit Terhadap Ketepatan Pemberian Opini Oleh Auditor (Studi Empiris Pada Inspektorat Kabupaten Buleleng, Kabupaten Bangli Dan Kabupaten Karangasem). Jurnal Akuntansi, 3(1), 1-12.

Suprianto, E. (2014). Pengaruh Time Budget Presure Terhadap Perilaku Disfungsional Auditor. Jurnal Akuntansi, 5(1), 57-65.

Surtikanti, L. L. (2016). Pengaruh Profesionalisme Akuntan Publik dan Perilaku Disfungsional Akuntan Publik Terhadap Kualitas Audit (Stusi Kasus pada Kantor Akuntan Publik di Bandung). Jurnal Akuntansi, 69-80.

Yuen, D. C. Y., Law, P. K. F., Lu, C., \& Guan, J. Q. (2012). Dysfunctional Auditing Behaviour: Empirical Evidence on Auditors' Behaviour in Macau. International Journal of Accounting and Information Management, 4(5), 1-20. 